rise to the suppression phenomenon ${ }^{3}$. However, as the cold agglutinins and the incomplete agglutinins appear to be identical, the mystery of the separability of component agglutinins for $O, A$ and $B$ erythrocytes and the increased thermal amplitude after absorption with red corpuscles of group $O$ remains to be solved.

Blood Transfusion Department, Armed Forces Medical College,

Poona.

July 19

${ }^{1}$ Krupe, M., Biol. Zentralbl., '72, 424 (1953).

2 Bird, G. W. G., Curr. Sci., 22, 273 (1953)

${ }^{3}$ Bird, G. W. G., Brit. J. Haemat. (in the press).

\section{Production of Diphtheria Toxin in Submerged Culture}

$W_{E}$ have shown ${ }^{1}$ that diphtheria toxin with a value of 150-200 flocculating units per $\mathrm{ml}$. can be obtained by growing the Park-Williams No. 8 strain of $C$. diphtheriae as a submerged culture, using a tryptic digest medium based on that described elsewhere ${ }^{2}$. The volumes employed were 10-14 litres of medium, and the vessels were of glass, with stirrers made of either 'Birmabright' (a magnesium-aluminium alloy) or aluminium.

In recent developments of this technique, we have used 80-litre tanks, made from commercial aluminium, which offer many advantages over glass vessels for routine toxin production. They permit of a much better control of temperature during the growth of $C$. diphtheriae and are more suitable for sterilization of the culture medium. Vortex stirring ${ }^{3}$ has been used, and sterile air at a rate of $0 \cdot 05-0 \cdot 15$ litre per min. per litre of culture medium has been found satisfactory.

The time required for maximal toxin production has been found to be very dependent on the size of the initial inoculum employed. For routine toxin production a growth period of the order of $48 \mathrm{hr}$. is very convenient, and for this an initial inoculum of $200 \mathrm{ml}$. of a $48-\mathrm{hr}$. shaken culture of $C$. diphtheriae for a volume of 50-60 litres of medium has been found satisfactory. If a much larger inoculum is used, for example, 10 litres of 24-hr. culture produced in a small seed-tank, peak toxin production is obtained in about $28 \mathrm{hr}$.

As an alternative mothod, we have withdrawn approximately half the culture when the peak toxin value has been reached and replaced it with an equal volume of fresh sterile medium. After this replacement, the toxin production is a maximum in $24 \mathrm{hr}$., and this procedure may be repeated many times, thus giving in effect a semi-continuous daily toxin production of 30 litres per tank. Unfortunately, the initial purity of the toxin, which is of the order of 1,500 Lf. units per mgm. protein nitrogen, is not maintained, and for this reason we prefer to harvest single batches of toxin rather than to run a semicontinuous process. An example of a result obtained in this way is shown in Table 1 .

With the equipment and methods now in use, we have been able to produce large volumes of culture filtrates from $C$. diphtheriae having an $\mathrm{Lf}$. value of the order of 180-250 units per ml. The advantages of submerged culture methods over the older surfaceculture technique are very obvious. Toxin production in shallow layers of culture medium necessitates the manipulation and inoculation of hundreds of bottles
Table 1. SUBMerged Culture No. 187 Aluminium tank with vortex stirrer, capacity 80 litres. Culture of a 24 -hr. growth of $C$. liphtheriae prepared in a small submerged culture tank. Air flow: 6 litres per min.

\begin{tabular}{|c|c|c|c|c|}
\hline $\begin{array}{l}\text { Growth time } \\
\text { (hr.) }\end{array}$ & $p \mathrm{H}$ & (U./ml. $)$ & $\begin{array}{c}\text { Protein } \\
\text { nitrogen } \\
\text { (mgm./ml.) }\end{array}$ & $\begin{array}{c}\text { Purity } \\
\text { (Lf./mgm. pro- } \\
\text { tein nitrogen) }\end{array}$ \\
\hline $\begin{array}{c}0^{*} \\
2 \\
4 \\
6 \\
8 \\
10 \\
12 \\
23 \\
25 \\
28 \dagger\end{array}$ & $\begin{array}{l}7 \cdot 85 \\
7 \cdot 65 \\
7 \cdot 72 \\
7.80 \\
7.82 \\
7 \cdot 87 \\
8 \cdot 05 \\
8 \cdot 30 \\
8 \cdot 40\end{array}$ & $\begin{array}{r}15 \\
17 \\
22 \\
34 \\
51 \\
69 \\
85 \\
206 \\
212 \\
235\end{array}$ & $\begin{array}{l}0 \cdot 138 \\
0 \cdot 154\end{array}$ & $\begin{array}{l}1,490 \\
1,510\end{array}$ \\
\hline $\begin{array}{l}29 \\
30 \\
32 \\
34 \\
36 \\
47 \\
49\end{array}$ & $\begin{array}{l}7.98 \\
7.88 \\
8.06 \\
8.10 \\
8 \cdot 18 \\
8.32 \\
8.49\end{array}$ & $\begin{array}{l}117 \\
114 \\
133 \\
155 \\
168 \\
252 \\
259\end{array}$ & $\begin{array}{l}0.126 \\
0 \cdot 195\end{array}$ & $\begin{array}{l}1,320 \\
1,330\end{array}$ \\
\hline
\end{tabular}

* Initial values after inoculation. + At $28 \mathrm{hr} .35$ litres of culture were removed and replaced by 30 litres of sterile culture medium.

-a laborious process where comparatively large amounts of culture filtrate are required. By the submerged culture method, however, large volumes of medium can be handled with ease and it is possible, for example, to take uniform samples at frequent intervals (for example, 2-hourly) throughout the growth period so that determinations of total growth, toxin production, and metabolic changes may be studied. Observations on these points and other factors which influence toxin production will be reported later.

Previously ${ }^{1}$, we stated that vessels made from commercial aluminium showed signs of attack on continued use, accompanied by a decrease in toxin production. The vessels now in use (of modified design) have not shown this attack, and there has been no decrease in toxin production on continued usage. Possibly a difference in composition of the aluminium used for the first experimental tank accounted for this finding.
F. V. LINGGOOD
A. C. Matritews
S. Pinfietid
C. G. POPE
T. R. Shartand

Wellcome Research Laboratories,

Langley Court,

Beckenham, Kent. July 29.

1 Linggood, F. V., Matthews, A. C., Pinfield, S., Pope, C. (7., and Sharland, 'T. R., Nature, 174, 557 (1954).

${ }^{2}$ Linggood, F. V., and Fenton, E. L., Brit. J. Exp. Path., 28, 35 (1947).

${ }^{3}$ Chain, E. B., Paladino, S., Callow, D. S., Ugolini, F., and Van Der Sluis, J., Bull. World Health Org., B, 73 (1952).

\section{Preservation of Rat Liver Nuclei by Potassium Glycerophosphate}

Appelmans and de Duve' found that the 'osmotic activation' or lysis undergone by rat liver mito. chondria in hypotonic media could be prevented by the presence in the medium of $0.25 M$ sucrose; the sucrose could be partly replaced by an iso-osmolar quantity of $\beta$-glycerophosphate. They showed that mitochondria released certain enzymes as a result of osmotic activation. If deoxyribonuclease, which 